\title{
超電導回転機の技術動向
}

\author{
大崎 博之*

\section{Technology Trends of Superconducting Rotating Machines}

\author{
Hiroyuki OHSAKI ${ }^{*}$
}

\begin{abstract}
Synopsis: The development of superconducting rotating machines based on metallic superconductors achieved many excellent results, for example, in the Super-GM project. However, since the end of the 20th century, the focus of development has shifted to developing high-temperature superconducting (HTS) machines. The initial target application was industrial motors for pumps and fans, but this has now changed to low-speed large-torque motors for ship propulsion. Recently large-capacity wind turbine generators have been attracting attention. Furthermore, the development of fundamental technologies for HTS turbine generators in thermal and atomic power stations has started. Excellent features such as smaller size, lighter weight and higher efficiency, and also improvement of functions and characteristics are expected in superconducting rotating machines. However, cost reduction and system reliability verification are still key issues for practical application of the HTS machines. This article describes superconducting rotating machine technologies and technical trends in their development, the fundamental structure and characteristics of the rotating machines, the Super-GM project based on the liquid helium cooling and NbTi metallic superconductor, and the development status of HTS rotating machines.
\end{abstract}

Keywords: high-temperature superconductor, motor, generator, ship propulsion, wind turbine

(Some figures in this article may appear in colour only in the electronic version)

\section{1. はじめに}

超電導回転機の研究は 1960 年代から始まり, 船舶の電 気推進のための単極機と大容量タービン発電機の開発が中 心であった ${ }^{1,2)}$ 。タービン発電機については，本格的な実用 機を目指した開発が旧西ドイツ，旧ソ連，米国で行われた が，いずれのプロジェクトも電力需要の低迷と資金難で中 止され，わが国の Super-GM プロジェクトが唯一， 7 万 $\mathrm{kW}$ のモデル機を製作し，系統連系試験まで実施した ${ }^{3)}$ 。

1986 年の高温超電導物質の発見以降は, 開発対象は高温 超電導回転機へと移っていった。高温超電導モータは，産 業部門の電力需要の $60 \%$ 以上を占めるモータの損失を低減 するための有望な技術として注目された。主にポンプや ファン用などの大型モータを対象に超電導技術の適用可能 性が検討され，米国を中心に研究開発が進められたが，そ の後, 対象は船舶推進用の低速・大トルクモータへと移り, 主に米国やドイツなどで大型回転機の開発と試験が行われ

\footnotetext{
Received June 5, 2012

*東京大学 大学院新領域創成科学研究科

T277-8561 千葉県柏市柏の葉 5-1-5

Graduate School of Frontier Sciences, The University of Tokyo,

Kashiwanoha 5-1-5, Kashiwa 277-8561, Japan

E-mail: ohsaki@k.u-tokyo.ac.jp
}

$た^{4,5)}$ 。

また最近は，地球温暖化問題に代表されるエネルギー・ 環境問題の解決あるいは軽減へ向けて, 自然エネルギーの いっそうの有効利用が求められ, 世界規模で導入拡大が進 む風力発電についても，洋上ウィンドファームの拡大，お よび発電機の単機容量の拡大が進められている。しかし, 出力とともに発電機（十増速機）重量は著しく増大するた め, 従来技術に基づく設計・製作および建設は急激に困難 になる。そこで, 超電導技術を適用する $10 \mathrm{MW}$ 級の大型 風力発電機が提案され, 研究開発が進められている ${ }^{6,7}$ 。

回転機は汎用性の高い機器であり，小規模のものから タービン発電機のように大容量のものまで様々なものがあ る。現在は輸送システム用の回転機や風力発電機の開発が 中心であるが, それらの技術開発が進行し, 実用化へ向け て技術が向上していけば，他の用途の回転機の要素技術の 高度化にもつながり, 将来的には機器適用領域の拡大やさ らなる技術発展が期待できよう。

中 ・大容量の回転機を対象に, 縦軸を定格出力 $(\mathrm{kW})$, 横軸を定格回転速度 $(\mathrm{rpm})$ とするグラフ上に, 代表的な応 用分野別におよその定格運転領域を Fig. 1 に示した。火力 発電・ 原子力発電用タービン発電機, 水力発電機, 船舶推 進用モータ, 産業用モータ, そして風力発電機の 5 つの応 


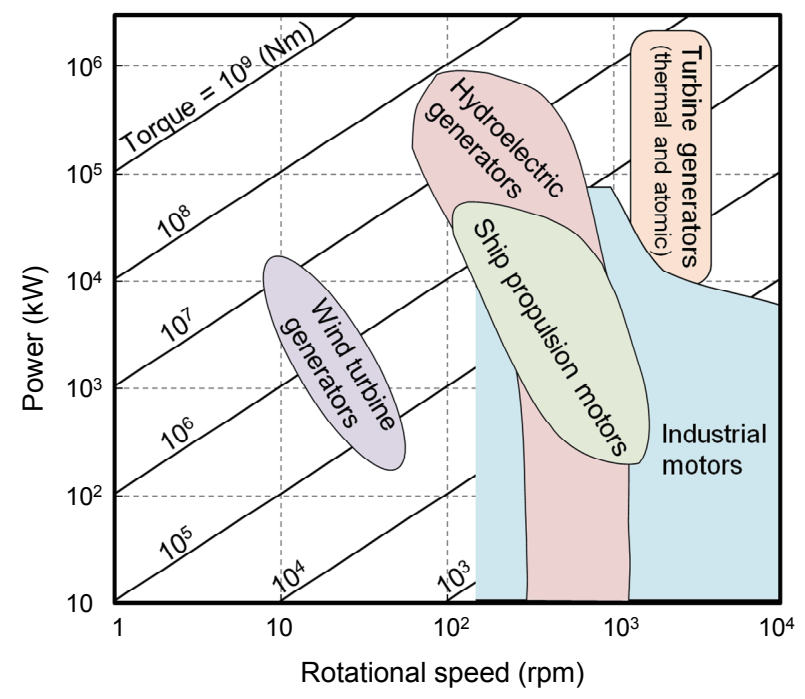

Fig. 1 Rated output power, rotational speed, and torque of medium- and high-power electrical rotating machines.

用分野である。ただし，風力発電機についてはダイレクト ドライブの風力発電機に限定している。また, 図中には出 力と回転速度から決まるトルクの特性線も $10^{3} \sim 10^{9} \mathrm{Nm}$ に ついて示した。トルクは発電機体格に対応すると考えてよ い。例えば，水力発電機の世界最大級のものは出力約 80 万 $\mathrm{kW}$, 定格回転速度 $110 \mathrm{rpm}$ 程度であり, そのトルクは 最大 $70 \mathrm{MNm}$ 近くに達し, 非常に大きい。また, $10 \mathrm{MW}$ 級のダイレクトドライブ風力発電機のトルクは $10 \mathrm{MNm}$ 程 度であり, 最大規模のタービン発電機の軸トルクよりも大 きい。この図から，10 MNm の軸トルクの回転機を小型軽 量化の要求と両立させながら設計することの難しさがわか るであろう。

超電導回転機としては超電導単極機も含まれ，研究開発 の初期の頃から今もなお開発は継続されているが, 開発の 主流は同期機であるので，本稿では，同期機を中心に，超 電導回転機の技術とこれまでの技術開発の動向について紹 介寸る。第 2 章は超電導回転機の基本構造と特長, 第 3 章 は液体ヘリウム冷却の NbTi 超電導コイルを使用した超電 導発電機開発 Super-GM プロジェクトの概要, 第 4 章は高 温超電導回転機の研究開発動向について概説する。

\section{2. 超電導回転機の基本構造と特長}

\section{1 アキシャル形とラジアル形}

回転機は, 電磁力（トルク）発生部の磁界主成分の向き によって，大きく 2 つに分けることができ，磁界が回転軸 方向に向いているアキシャル形と, 径方向に向いているラ ジアル形がある（Fig. 2）。一般的なのはラジアル形である が，低速機などではアキシャル形の選択もあり，多層化す ることにより高出力 (密度) 化が可能である。

また，回転機には回転子側に界磁がある回転界磁形と電 機子がある回転電機子形の 2 つがある。大きな電機子電流
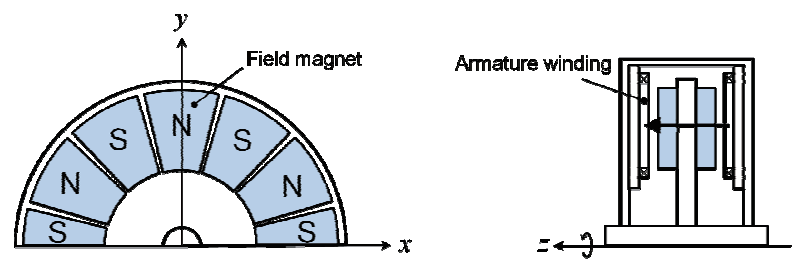

(a) Axial type

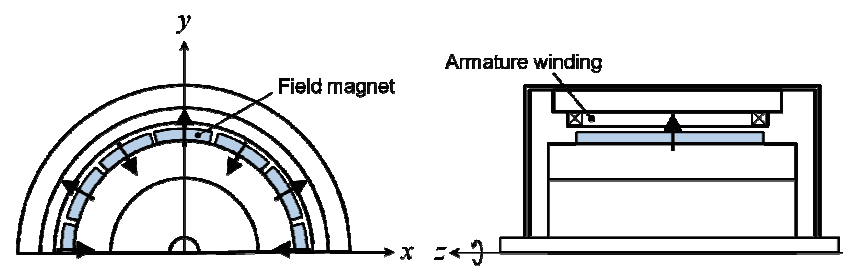

(b) Radial type

Fig. 2 Fundamental structure of a rotating machine. Classification is based on the direction of the magnetic field (arrows show the direction of the magnetic field).

が流れる大型機では，電機子を回転子側にするのは技術的 に難しく，回転界磁形が一般的である。以下では回転界磁 形を対象にする。

\section{2 固定子と回転子の構造}

次に, 超電導回転機の開発において最も一般的な構造で あるラジアル形同期機について, 固定子と回転子の基本的 な構造を整理する。電機子巻線を有する固定子側は, 空隙 電機子巻線にバックヨークを組み合わせる構造と, スロッ 卜有りの鉄心を用いてそのスロットに電機子巻線が入る構 造の 2 種類がある (Fig. 3)。磁束密度を高く設計する超電 導機では空隙電機子巻線が選択されることも多い。一方, スロット有り鉄心を用いると, 磁気的ギャップ長が縮ま り, ギャップ磁束密度の増大には有効である。しかし, 超 電導機では磁束密度が大きく, 特にティース部分の磁気飽 和が非常に強くなるので, 大きな電磁力や損失に十分対応 した設計をする必要がある。磁束密度の大きさによっては 有効な構造である。

一方, 回転子側は, Fig. 4 に示すように, 鉄心の無い空 心界磁コイルのみの場合, 空心界磁コイルにバックアイア ンを組み合わせた場合，および突極構造の鉄心と界磁コイ ルを組み合わせた場合の 3 通りが考えられる。回転子側を 突極構造, 固定子側を Fig. 3 (b)のスロット有り鉄心を組み 合わせると，鉄心磁気回路を有効に利用する構造となる。 磁束密度が超電導機としてはあまり高くはない場合には有 効であるが, 界磁コイルの低温容器（クライオスタット） や界磁コイル系の電流リードについては詳細な検討が必要 である。

\section{3 回転機容量とトルク}

同期機の容量 $P[\mathrm{kVA}]$ とトルク $T[\mathrm{Nm}]$ は以下の式で表す ことができる ${ }^{3)}$ 。 


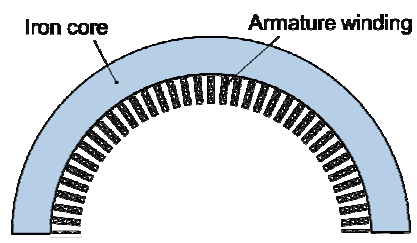

(a) Air-gap windings with back yoke

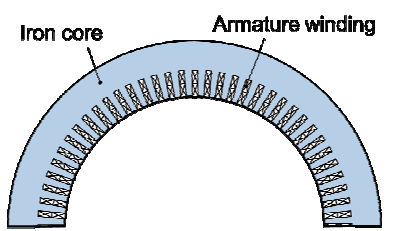

(b) Armature windings in the slots of stator yoke
Fig. 3 Stator structure with armature windings.

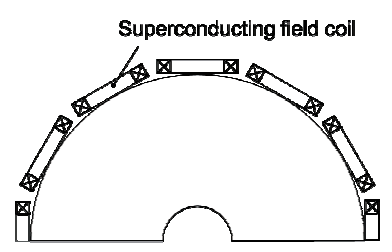

(a) No iron core

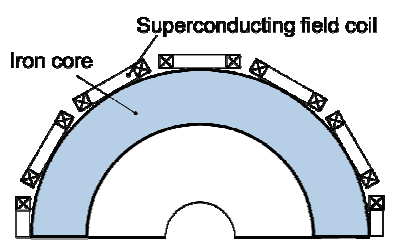

(b) With back iron

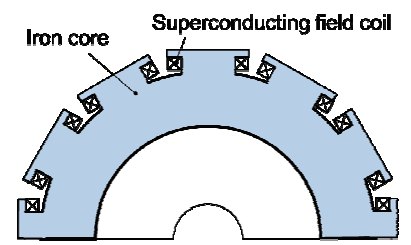

(c) Salient pole type

Fig. 4 Rotor structure with field coils.

$$
\begin{aligned}
& P=k \cdot B_{g} \cdot A C \cdot D^{2} L \cdot n \\
& T \propto B_{g} \cdot A C \cdot D \cdot D L
\end{aligned}
$$

ここで, $k$ は定数， $B_{g}$ はギャップ磁束密度（磁気装荷） $[\mathrm{T}], A C$ は電気装荷 $[\mathrm{A} / \mathrm{m}], D$ は回転子外径 $[\mathrm{m}], L$ は固定 子鉄心長 $[\mathrm{m}], n$ は回転速度 $[\mathrm{rpm}]$ である。 $D^{2} L$ は回転機サイ ズに相当する。電気装荷 $A C$ は電機子巻線部の単位周長当 たりの総電流である。仕様で与えられる回転速度で，ある サイズ制約のもとで，回転機容量を大きくするためには， 電気装荷と磁気装荷を上げる必要がある。磁気装荷は界磁 コイル電流（アンペアターン）の増大, 高性能永久磁石の 導入，磁気回路の工夫などにより，大きくすることは可能 であるが，磁気回路に使用される電磁鋼板等の磁気飽和の ため一般には限界がある。電気装荷は主に電機子巻線の冷 却技術の進歩によって増大寸る。過去のタービン発電機の 開発の経緯を見ても, 冷却方式の進歩などにより大容量化 が進んだが，一方で，大容量化に伴う運転制約や系統運用 上の影響等の問題も現れてきた。それを打開しつつ，大容 量化をさらに進めるための革新技術として，1970 年代から 超電導発電機の研究開発が進められた ${ }^{3)}$ 。

大容量かつ大トルク・低速の回転機には, 直径を大きく して極数を増やす設計の方が一般的によい。しかし，超電 導機においてしばしば選択される，鉄心がバックアイアン やバックヨークのみで磁気的なギャップが大きい場合で
は, 極数が多く, 極ピッチが相対的に短くなると漏れ磁束 が多くなり, 特性がかえって下がるので, 適切な極数の選 択が必要である。

\section{4 超電導回転機の基本構造}

超電導回転機の基本構造の一例を Fig. 5 に示す。固定子 側の電機子巻線が FRP などの非磁性構造材で固定されてい る場合であり，その背後に電磁鋼板を使用したバックヨー クが磁気シールドとして機能する。回転子は, 冷媒によっ て冷却される超電導界磁コイルを有し, 界磁コイルにかか るトルクはトルクチューブと回転軸を介してタービンや負 荷につながる。回転子の真空容器壁は常温ダンパとしても 機能する。トルクチューブはトルク伝達と断熱という相反 する機能を持たなければならず, 超電導回転機の重要構成 要素の一つであり，特に大トルク機では技術的な難易度が 高くなる。

\section{5 超電導回転機の特長}

回転機の界磁コイルを超電導化することによって得られ る特長について, すでにいくつか紹介してきたが, 以下に それらも含めて重要な特長を整理する。

(1) 大容量化，小型・軽量化

超電導回転機の代表である同期機の出力は，式(1)に示し たように, ギャップ磁束密度に比例する。常電導機の ギャップ磁束密度は, 磁束の通り道である磁気回路を構成 する電磁鋼板等の磁気飽和や界磁コイルの起磁力制約など により高々 $1 \mathrm{~T}$ 程度である。しかし超電導機では, 高電流 密度の超電導界磁コイルの大きな起磁力によってギャップ 磁束密度の向上が可能であり, 結果として, 同程度のサイ ズで考えれば機器の大容量化が実現でき, 同程度の出力で 考えれば機器の大幅な小型・軽量化が可能となる。

(2) 高効率化

界磁コイルの超電導化により, 界磁コイルのジュール損 失が大幅に低減でき，また，機器の小型軽量化にともな い，機械損や漂遊損なども低下寸る。発電所設置の大容量 タービン発電機への適用を考えた場合は, 冷凍機動力を考 慮しても，損失合計が現用機と比較して半分以下に低減で

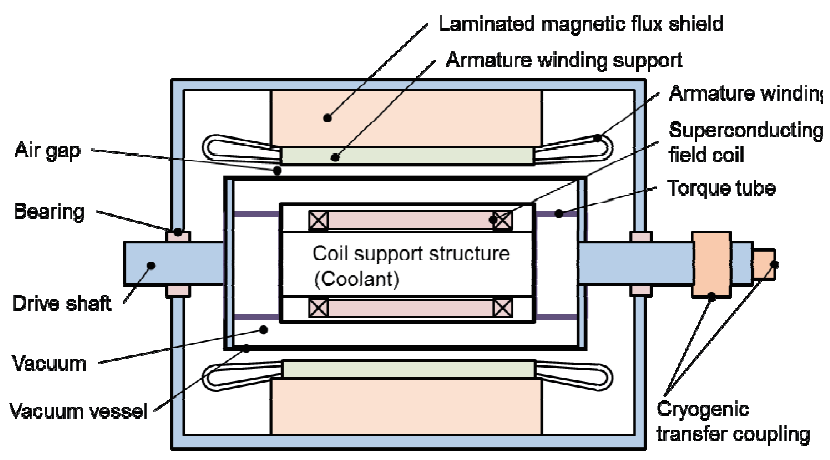

Fig. 5 Fundamental structure of a superconducting rotating machine. 
きるという設計が示されている ${ }^{3)}$ 。大容量機の効率はもと もと 98〜99\%と高く, 超電導化による効率向上は $0.5 \sim 1 \%$ 程度であるが，損失低減量としては決してわずかではな く，大きなメリットである。

以上は超電導機に共通のメリットであるが，次に，特に 超電導同期発電機において重要な特長を 2 点紹介する。

(3) 低同期リアクタンス

現用常電導機と超電導機の典型的な構造を Fig. 6 に示 す。現用機では固定子, 回転子共に鉄磁気回路で構成さ れ, 界磁コイルによって電機子側に効率的に磁界を発生す るようになっている。電機子巻線側からみても, 電機子電 流が磁束を発生しやすい構造になっていて, 電機子巻線イ ンダクタンスが比較的大きい。そのため現用機の同期リア クタンスが単位法表記で 2 を超えるような発電機もある。

一方，超電導機は磁束密度が高い設計であるため，鉄心が 飽和しやすいので，鉄心の利用は Fig. 6 (b)の例で示すよう に，固定子バックヨークだけなどに限ることも多く，その ため, 電機子巻線のインダクタンスは小さく, 同期リアク タンスは $0.3 \sim 0.5$ 程度と非常に低い設計が可能である。

同期リアクタンスは電気回路モデルで考えれば，Fig. 7 に示すように出力インピーダンスであるので，同期リアク タンス $X_{d}$ が大きいと負荷電流によって発電機出力電圧 $\dot{V}$ が変動しやすい。つまり, 機器の電圧安定性が悪いという ことであり，実際の発電機ではそれを制御によってカバー している。一方，低同期リアクタンスの超電導機は，本質 的に電圧安定性が良好である。さらに，低同期リアクタン スは, 発電機が電力系統に接続されたときの送電可能電力 の増加にも寄与する。

ただし，超電導機で同期リアクタンスが常に非常に低い 訳ではなく, 小型軽量化をより重視して, 鉄心の利用を増

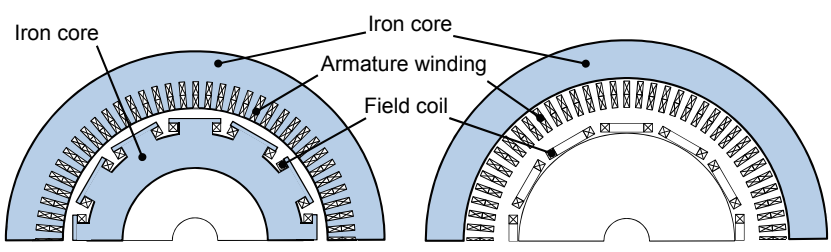

Fig. 6 Typical structures of a conventional machine (left) and a superconducting machine (right).

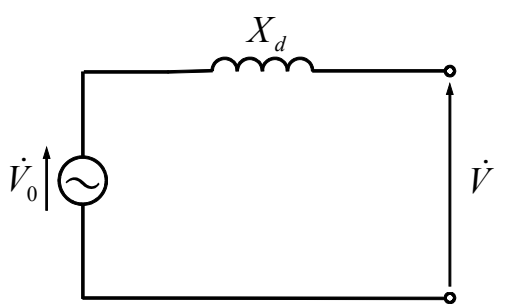

Fig. 7 A simplified equivalent circuit of a power generator. ( $\dot{V}_{0}$ : no-load induced voltage, $X_{d}$ : synchronous reactance).
やし，同期リアクタンスはやや大きめの設計をするという 選択もある。

（4）運転可能範囲が広い

発電機は, 有効電力を供給するだけでなく, 電力需要 （負荷）に合わせて無効電力も供給することが必要であ る。現用機では, 進相運転領域で, 固定子鉄心端部での過 熱や定態安定度低下などの問題のため, 制限を受けるが, 超電導機では, 進相運転領域でも定格電流までの運転が可 能である。

\section{Super-GM 発電機研究開発プロジェクト}

わが国では 1970 年代より, タービン発電機への超電導 技術の適用が検討されるようになり，設計研究やいくつか の小型機による基礎研究を経て, 通商産業省工業技術院の ニューサンシャイン計画の一環として, 1988 年度から 1999 年度にわたって, 超電導電力応用技術（Super-GM） プロジェクトが進められた ${ }^{3)}$ 。20 万 $\mathrm{kW}$ 級パイロット機の 設計・製作技術の研究開発と， 20 万 $\mathrm{kW}$ 級機の $1 / 3$ 縮小 モデルとしての 7 万 $\mathrm{kW}$ 級モデル機の設計・製作・試験が 行われた。1/3 縮小モデルは 20 万 $\mathrm{kW}$ 級概念設計機の同 径縮長モデルである。

この超電導発電機は, 同規模の現用発電機に対して小型 軽量であり，界磁損と機械損の低減等により効率が約 $0.5 \%$ 向上し，同期リアクタンスが 0.4 と低くて安定度も向上 し，進相運転領域の制約が無くなることによる運転可能範 囲拡大等の優れた特長を有する。

周波数 $60 \mathrm{~Hz}$, 回転速度 $3600 \mathrm{rpm}, 2$ 極の超電導タービ ン発電機の超電導回転子として，2 種類の低速応形と 1 種 類の超速応形が製作, 試験された。回転子側では, それぞ れに対応した 3 種類の超電導導体, 低温ダンパや常温ダン パ，トルクチューブ, 熱収縮吸収機構, ヘリウム給排装置 などの要素技術が開発された。固定子は 1 台で共通に使用 され, 空隙電機子巻線, 二重転位導体, 磁気シールド, 電 機子導体固定構造などが開発された。冷却は液体へリウム

$(4.2 \mathrm{~K})$ による浸漬冷却であり，120 l/h の液化能力をもつ 冷凍システムも開発された。

7 万 $\mathrm{kW}$ 級モデル機は, 関西電力大阪発電所構内で試験 が行われ, 発電出力 7 万 $9000 \mathrm{~kW}$, 効率 $99.3 \%, 1500$ 時間 連続運転等などを達成し, さらに系統連系試験も実施し, $77 \mathrm{kV}$ 商用電力系統に連系して 4 万 $\mathrm{kVar} の$ 無効電力の供給 に成功した。

その後, 2000 年度から 2003 年度の 4 年間は, 超電導発 電機基盤技術プロジェクトとして，いっそうの高密度化と 大容量化のための基盤技術の研究開発, および設計技術確 立へ向けた開発が行われた。しかしその後は, 実用化へ向 けた技術開発を継続することはできず，開発された超電導 発電機技術の成果は残念ながら十分に活かされているとは 言えない。 


\section{4. 高温超電導回転機の研究開発}

\section{1 最近の全体的な技術動向}

高温超電導回転機技術としては，米国やドイツを中心に これまで比較的大型の舶用モー夕等の開発がされ，最近は 日本，韓国，中国などでも MW 級のモータが開発されてい る。また, 大容量風力発電機の設計研究なども進められて いる。

電気推進船は，プロペラの推進軸を駆動する原動機とし て電動機を使用する船舶であり，ディーゼル機関の場合に 必要な長い駆動シャフトが不要で, 発電機から電動機まで 各種機器を分散配置できるため, 各設備の自由な配置によ り船形の最適設計ができる, 高効率で操船性能に優れる, 振動・騒音が低い，などの特徵を有する。舶用電動機の回 転数は一般に数百 $\mathrm{rpm}$ と低速である。その電動機と発電機 を超電導化するのが超電導電気推進船であり, 電気推進シ ステムの小型軽量化, 高効率化, あるいは大型船舶へ向け た大出力・大馬力化が可能となる ${ }^{1,4)}$ 。また, ポッド式電気 推進は, 特に超電導技術導入による小型軽量, 高効率化の 利点を享受できる。

最近注目されているのが風力発電機の超電導化である。 発電コストの低減のために風力発電の大型化が進み, 現在 の主流は 2〜3 MW である。風車の直径が大きくなると, 風車の平均高さも高くなり, 高度の高いところの条件のよ い風を発電に利用でき，大型化により敷地面積当たりの発 電電力が増大可能である。技術開発の進歩と共に, 風力発 電システムのコスト低減も進み, 風力発電の大型化が進ん でいる。洋上風力発電のためにさらに大型化が行われ，最 近は 6 7 MW 機の開発と導入が進みつつある。今後の市 場を狙って，すでに $10 \mathrm{MW}$ 級機の研究開発が着手され， その上の 15〜20 MW 級機も提案されている。また, 大容 量機ではダイレクトドライブの同期発電機が主力となって いる。大出力ダイレクトドライブ同期機は，低速，大卜ル ク，大型となる。そのため単機発電出力の増大は発電機の 重量・サイズの増加と, タワートップ重量の増加を招くの で，発電機重量・サイズの低減は重要課題であり，そのた めに超電導発電機の可能性が検討されている ${ }^{6,7)}$ 。現在ター ゲットとなっているのは $10 \mathrm{MW}$ 級機であり, この場合, 風車直径が $160 \sim 180 \mathrm{~m}$ ，回転数約 $10 \mathrm{rpm}$ である。風力発 電は大型化がどんどん進展し，コスト競争の激しい分野で あり，超電導機においても高性能化と同時に低コスト化が 強く求められる。そのため, 使用される超電導線材量をい かに抑えるかが重要課題となっている。

火力・原子力発電用のタービン発電機も再び検討が始 まっており ${ }^{8)}$, 自動車や航空機用のモータの研究開発も行 われている9

\section{2 日本}

わが国においては Super-GM プロジェクトの後, 回転機 開発を目的とする大型プロジェクトはしばらく無く, 比較 的小規模な研究開発が, 船舶用モータを中心に産学連携で 進められてきた。その中には，アキシャル形モータやバル ク超電導体の界磁への適用なども含まれている ${ }^{10)}$ 。ここ数 年は川崎重工業を中心とする研究グループで研究開発が盛 んに進められ，NEDO の省エネルギー革新技術開発事業で は，2010２012 年度に実用化開発フェーズとしての船舶用 高温超電導モータ内蔵ポッド推進システム実用化のための 研究開発が進められ, 内航船向けの $3 \mathrm{MW}$ 高温超電導モー タが開発中である。また, JST の戦略的イノベーション創 出事業の中で, 2009 年度から 5 年計画で船舶推進用 20 MW 級の高効率かつコンパクトな高温超電導回転機の実現 に向けた技術の確立を目指して研究開発が進められている 11)。

また，かご形誘導モータの回転子側かご形導体を高温超 電導化し, 定常状態では同期運転となる高温超電導誘導同 期機が提案され, 自動車用を主目的として, 精力的に実証 試験等が行われている ${ }^{12)}$ 。

回転機への適用の基礎となるレーストラック形 $\mathrm{RE}$ 系超 電導コイルの製作もいくつかの研究グループで進められて いる ${ }^{13)}$ 。また, 超低速, 大卜ルク回転機である大容量風力 発電機への超電導技術の適用についても, 設計研究を中心 にわが国でも精力的に研究が行われている ${ }^{6,7}$ 。

\section{3 米国}

米国における高温超電導モータ開発の開始は早く, Rockwell Automation 社は 1996 年に 200 馬力機, 2000 年に 1000 馬力機の試験を実施している 5)。いずれも 4 極, 60 $\mathrm{Hz}, 1800 \mathrm{rpm}$ のモータであり, 超電導界磁コイルは American Superconductor (AMSC)社が製作した。その後, モータ開発自体も AMSC 社が行うようになり, 2001 年に 5000 馬力, $1800 \mathrm{rpm}$ モータを製作し, 試験を実施した。そ の後, 船舶推進用の低速モータの開発に移行し, 2003 年に $5 \mathrm{MW}, 230 \mathrm{rpm}$ 機を, 2007 年には $5 \mathrm{MW}$ 機のスケール アップ機として $36.5 \mathrm{MW}, 120 \mathrm{rpm}$ 機を製作し, 試験を実 施した。いずれも Bi2223 線材が使用されている。36.5 MW モータのトルクは2.9 MNm に達し, すでに実用されている 大型回転機と比較しても, トルクの大きい機器に分類でき る（Table 1）。全負荷試験は 2008 年に実施された。37.5 MW 入力で 4 時間余りの試験が行われ, 設計值である 36.5 MW 出力が実証され, また, 試験データより約 $1 \mathrm{MW}$ の損 失があることも算出された ${ }^{14)}$ 。この成果を活かして, 同社 はその後, 8〜10 MW 出力の超電導風力発電機の検討を進 め, 設計された $10 \mathrm{MW}$ 機は外径 $5 \mathrm{~m}$ 以下で重量約 160 卜 ンとなり, 従来技術と比較して軽量化のメリットが大きい ことを示している。 
また, AMSC 社は無効電力補償に利用される超電導同期 調相機の 8 MVar および 12 MVar のプロトタイプ機も開発 した ${ }^{5,15)}$ 。アーク炉によるフリッカ対策を目的に, 2004 年 10 月にテネシー川流域開発公社 TVA の $13.8 \mathrm{kV}$ 系統に 8 MVar 機が導入され，1 年間運転された。その後，12 MVar 機を実用機として納めた。しかし, 超電導線材や冷却シス テムコストがなお実用化の上での問題として残り, まだあ まり普及はしていない。

General Electric (GE)社は，100 MW，3600 rpm，2 極の超 電導発電機の開発を行った ${ }^{5,16)}$ 。界磁コイルを超電導化し, 回転子に鉄心コアも利用した。また, 固定子側は従来機同 様の鉄心構造であり，従来機の回転子のみの置き換え

（Retrofit）が可能な設計であった。

\section{4 ドイッ}

ドイツの Siemens 社では 1999 年に高温超電導回転機の研 究開発を本格的に開始した ${ }^{17)}$ 。第一フェーズでは, $400 \mathrm{~kW}$ のモータを製作し，高温超電導コイルの製作技術，トルク チューブ技術, 冷却技術, 電機子巻線技術などの成立性を, 設計・製作および試験を通じて検証し，比較的小出力では ありながら，その後のスケールアップにつながる技術の確 立を目的に開発が進められた（Table 2） ${ }^{18)}$ 。また，低りア クタンス機の高い電圧安定性や過負荷耐量なども実験的に 検証し，モータおよび発電機の両モードでの試験も行われ た。

$400 \mathrm{~kW}$ 機による成果を受けて，第二フェーズが 2002 年 から開始され, 実用規模と言える 4 MVA， $3600 \mathrm{rpm}$ 超電導 発電機が製作され，その技術的優位性の検証が行われた ${ }^{19)}$ 。 発電機の損失は, 冷却効率を考慮しても現用機の半分以下 となり，効率は現用機の 96.1\%から 98.4\%に向上した

（Table 3)。また, 冷却システムは複数の冷凍機を並列運 転し，発電機を停止すること無く冷凍機本体の交換が可能 な構成をとっていて，その検証も実施された。

2005 年からは第三フェーズに移行し，4 MVA，120 rpm

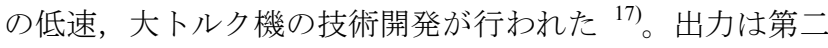
フェーズの発電機と同等であるが，低速であり，トルクは 30 倍程度と非常に大きく, 回転機サイズも大きい（Table 4)。使用された高温超電導線の長さは約 $45 \mathrm{~km}$ である。

Siemens 社は, 超電導コイルのための冷却システムとし

Table 1 AMSC 36.5-MW ship propulsion motor

\begin{tabular}{ll}
\hline Output & $36.5 \mathrm{MW}$ \\
Voltage & $6 \mathrm{kV}$ \\
Speed & $120 \mathrm{rpm}$ \\
Torque & $2.9 \mathrm{MNm}$ \\
No. of poles & 8 poles \\
Weight & 75 tons \\
Efficiency & $>97 \%$ \\
\hline
\end{tabular}

て，ネオンを泠媒としてサーモサイフォン効果を利用し， GM 冷凍機と組み合わせたシステムを開発し, 使用してい る。

2011 年 2 月, Siemens 社はカールスルーエ工科大学と共 同で高温超電導タービン発電機の研究開発をスタートした ことを発表した ${ }^{8)}$ 。長期的には出力が数十万 $\mathrm{kW}$ の高温超 電導タービン発電機の開発を目指している。

\section{5 韓国}

韓国では, DAPAS プログラムの中で, 2001 年から超電 導モータの開発が Doosan 社と韓国電気研究院 KERI によっ て行われてきた。2001〜2003 年の第一フェーズでは 100 馬 力モータ，2004２006 年の第二フェーズでは $1 \mathrm{MW}$ 級モー タ，2007２010 年の第三フェーズでは $5 \mathrm{MW}$ 級モータの開 発が行われた ${ }^{20,21)}$ 。Table 5 に $1 \mathrm{MW}$ モータの諸元を示す。 回転中の振動の問題により，定格負荷トルク条件で 1800 rpm までしか試験は行われていない ${ }^{22)}$ 。また 2011 年秋の 段階で試験実施中であった $5 \mathrm{MW}$ モータの諸元を Table 6 に示す。

\section{6 その他}

Converteam 社は, 既設の水力発電機の回転子だけを置換

Table 2 Siemens 400-kW model machine (1999-2002)

\begin{tabular}{ll}
\hline Output & $400 \mathrm{~kW}$ \\
Voltage & $3-50 \mathrm{~Hz}, 400 \mathrm{~V} \mathrm{AC}$ \\
Speed & $1,500 \mathrm{rpm}$ \\
Torque & $2,600 \mathrm{Nm}$ \\
Synchronous reactance & 0.15 \\
Rotor cooling power & $25 \mathrm{~W} @ 25 \mathrm{~K}$ \\
\hline
\end{tabular}

Table 3 Siemens 4-MVA, 3,600-rpm generator (2002-2005)

\begin{tabular}{ll} 
Output & $4 \mathrm{MVA}$ \\
Voltage & $3-60 \mathrm{~Hz}, 6.6 \mathrm{kV} \mathrm{AC}$ \\
Speed & $3,600 \mathrm{rpm}$ \\
Torque & $10.6 \mathrm{kNm}$ \\
No. of poles & 2 \\
Synchronous reactance & $0.33-0.51 \mathrm{p} . \mathrm{u}$. \\
Weight & 6.9 tons \\
Power factor & 0.8 \\
Efficiency & $98.4 \%$ \\
\hline
\end{tabular}

Table 4 Siemens 4-MW, 120-rpm motor (2005-2010)

\begin{tabular}{ll} 
Output & $4 \mathrm{MW}$ \\
Voltage & $3.1 \mathrm{kV} \mathrm{AC}$ \\
Speed & $120 \mathrm{rpm}(30-190 \mathrm{rpm})$ \\
Torque & $320 \mathrm{kNm}$ \\
No. of poles & 8 \\
Weight & 37 tons \\
\hline
\end{tabular}


する目的で超電導回転子の製作を行った ${ }^{23)}$ 。水力発電機の 諸元は Table 7 に示す通りである。固定子側は従来のまま の Retrofit 形であり, ドイツの Hirschaid 水力発電所の発電 機の回転子が対象である。界磁超電導コイルには Bi2223 線 材が使用され，ガスヘリウムにより $30 \mathrm{~K}$ 程度に冷却され る。高効率，コンパクト設計に特長があり, 出力が 1.25 MVA から 1.79 MVA に増大し, 同期リアクタンスは 4.3 か ら 0.2 に低下，効率は $86 \%$ から $98.5 \%$ に上昇する。同社は 8 MW 級の超電導風力発電機の検討も行っていた。なお, Converteam 社は 2011 年に GE 社傘下の GE Energy 社によっ て買収された。

デンマーク工科大学 (DTU) でも $10 \mathrm{MW}$ 超電導発電機 の設計を行い, その発電機外径は $4.7 \mathrm{~m}$, 運転温度 $20 \mathrm{~K}$, 16 極, 最大経験磁界 $9.1 \mathrm{~T}$ というような設計パラメータと なっている ${ }^{24)}$ 。

\section{5. まとめ}

大型高温超電導回転機の研究開発で先行していた米国と ドイツでは状況や方向性に変化が見られ，米国では風力発 電機に重点が移りつつあるが，まだ本格的なハードウェア 開発にはなっていない。ドイツでは，発電所用のタービン 発電機のための基盤技術開発がスタートした。実用機の導 入，普及につなげていくためには，なおコスト低減や信頼

Table 5 Korean 1-MW, 3,600-rpm motor

\begin{tabular}{ll}
\hline Output & $1 \mathrm{MW}$ \\
Voltage & $60 \mathrm{~Hz}, 3.3 \mathrm{kV} \mathrm{AC}$ \\
Speed & $3,600 \mathrm{rpm}$ \\
Torque & $2,650 \mathrm{Nm}$ \\
Synchronous reactance & $0.13 \mathrm{p.u}$. \\
No. of poles & 2 \\
Field coil temperature & $30-35 \mathrm{~K}$ \\
\hline
\end{tabular}

Table 6 Korean 5-MW, 210-rpm motor

\begin{tabular}{ll}
\hline Output & $5 \mathrm{MW}$ \\
Voltage & $10 \mathrm{~Hz}, 6.6 \mathrm{kV} \mathrm{AC}$ \\
Speed & $210 \mathrm{rpm}$ \\
Synchronous reactance & 0.25 p.u. \\
No. of poles & 6 \\
\hline
\end{tabular}

Table 7 Converteam hydroelectric generator

\begin{tabular}{ll}
\hline Output & $1.79 \mathrm{MW}$ \\
Voltage & $5.25 \mathrm{kV}$ \\
Speed & $214 \mathrm{rpm}$ \\
Torque & $77.3 \mathrm{kNm}$ \\
No. of poles & 28 poles \\
Weight & 32.7 tons \\
\hline
\end{tabular}

性等の実証が必要である。わが国や韓国, 中国などでは MW 級の回転機開発が現在も進められていて, 技術的な成 果とともに, 実用化へ向けた戦略的な取り組みを期待した い。

超電導回転機の設計において, 電磁設計, 機械・構造設 計, 熱設計は従来機と同様に重要であり, その複雑さは従 来機以上と言える部分もある。特に大トルク機の設計にお いては, トルクを伝達しつつ, 良好な断熱が求められるト ルクチューブがたいへん重要なコンポーネントである。超 電導機としての軽量・コンパクト性を活かし，かつ電磁力 支持構造を考慮した電磁設計と, 強力な電磁力・トルクに 対応した機械・構造設計，および回転機を効率的に冷却す る熱設計の技術のいっそうの向上と確立が必要である。ま た, 冷却システム, 電力変換器, 電力ネットワークと接続 する設備等ももちろん重要である。

わが国では Super-GM プロジェクトで 200 MVA 級タービ ン発電機の設計と, その縮小モデルとして 70 MVA 機を設 計, 製作, 試験をした実績があるが, 高温超電導機につい ては Super-GM 規模の大型プロジェクトはこれまで無く, 今後, 超電導回転機の設計, 製作技術の向上と機器実用化 の加速のためにも研究開発の推進が大いに望まれるところ である。

\section{参 考 文 献}

1) 電気学会大学講座 :「超電導工学 改訂版」, オーム社, 東京 (1988)

2) 仁田旦三 編著 :「超電導エネルギー工学」, オーム社, 東京 (2006) 160-166, 178-179

3) 上之溒博 編著：「超電導発電機」，オーム社，東京 (2004)

4) E.A. Bretz: "Super conductors on the high seas - ship propulsion using superconductor motors -," IEEE Spectrum 41 (2004) 60-67

5) S.S. Kalsi: "Applications of high temperature superconductors to electric power equipment," John Wiley \& Sons, New Jersey (2011) $59-128$

6) S. Fukui, J. Ogawa, T. Sato, O. Tsukamoto, N. Kashima and S. Nagaya: "Study of 10 MW-class wind turbine synchronous generators with HTS field windings," IEEE Trans. Appl. Supercond. 21 (2011) 1151-1154

7) Y. Terao, M. Sekino and H. Ohsaki: "Electromagnetic design of 10 MW class fully superconducting wind turbine generators," IEEE Trans. Appl. Supercond. 22 (2012) to be published

8) Siemens: "Pictures of the Future," Spring 2011 (2011) 7

9) P.J. Masson and C.A. Luongo: "High power density superconducting motor for all-electric aircraft propulsion," IEEE Trans. Appl. Supercond. 15 (2005) 2226-2229

10) M. Miki, S. Tokura, H. Hayakawa, H. Inami, M. Kitano, H. Matsuzaki, Y. Kimura, I. Ohtani, E. Morita, H. Ogata, M. Izumi, H. Sugimoto and T. Ida: "Development of a synchronous motor with a Gd-Ba-Cu-O bulk superconductors as pole field magnets for propulsion system," Supercond. Sci. Technol. 19 (2006) 494-499 
11) K. Umemoto and T. Yanamoto: "Current status of research \& development of high-temperature superconducting motor for ship propulsion,” TEION KOGAKU 47 (2012) 377-383 (in Japanese) 梅本勝弥, 柳本俊之：「船舶推進用高温超電導モー夕の研究 開発の状況」, 低温工学 47 (2012) 377-383

12) T. Nakamura, K. Matsumura, T. Nishimura, K. Nagao, Y. Yamada, N. Amemiya, Y. Itoh, T. Terazawa and K. Osamura "A high temperature superconducting induction/synchronous motor with a ten-fold improvement in torque density," Supercond. Sci. Technol. 24 (2011) 015014

13) M. Ogata, K. Mizuno, Y. Arai, H. Hasegawa, T. Sasakawa and K. Nagashima: "Trial manufacture of small HTS magnet using $2 \mathrm{G}$ tapes for maglev train application," IEEE Trans. Appl. Supercond. 21 (2011) 1556-1559

14) G. Snitchler: "Progress on high temperature superconductor propulsion motors and direct drive wind generators," 2010 International Power Electronics Conference (IPEC-Sapporo 2010) (2010) 5-10

15) W. Sweet: "Adrenaline for the grid -superconducting synchronous condenser -," IEEE Spectrum 43 (2006) 44-47

16) S.S. Kalsi, K. Weeber, H. Takesue, C. Lewis, H.-W. Neumüller and R.D. Blaugher: "Development status of rotating machines employing superconducting field windings,” Proc. IEEE 92 (2004) 1688-1704

17) W. Nick, J. Grundmann, J. Frauenhofer: "Test results from Siemens low-speed, high-torque HTS machine and description of further steps towards commercialisation of HTS machines," Physica C (2012) in press

18) W. Nick, G. Nerowski, H.-W. Neumüller, M. Frank, P. van Hasselt, J. Frauenhofer and F. Steinmeyer: "380 kW synchronous machine with HTS rotor windings - development at Siemens and first test results," Physica C 372-376 (2002) 1506-1512
19) W. Nick, M. Frank, G. Klaus, J. Frauenhofer and H.-W. Neumüller: "Operational experience with the world's first $3600 \mathrm{rpm} 4$ MVA generator at Siemens," IEEE Trans. Appl. Supercond. 17 (2007) 2030-2033

20) Y.K. Kwon, H.M. Kim, S.K. Baik, E.Y. Lee, J.D. Lee, Y.C. Kim, S.H. Lee, J.P. Hong, Y.S. Jo and K.S. Ryu: "Performance test of a 1 MW class HTS synchronous motor for industrial application," Physica C 468 (2008) 2081-2086

21) S.K. Baik, Y.K. Kwon, H.M. Kim, S.H. Kim, J.D. Lee, Y.C. Kim, H.J. Park, W.S. Kwon and G.S. Park: "Electrical parameter evaluation of a $1 \mathrm{MW}$ HTS motor via analysis and experiments," Cryogenics 49 (2009) 271-276

22) K.C. Seong and Y.S. Jo: "Progress and future prospects of superconductivity technologies for advanced power system in KOREA," Abstracts of CSSJ Conference 85 (2011) 98

23) R. Fair, C. Lewis, J. Eugene and M. Ingles: "Development of an HTS hydroelectric power generator for the Hirschaid power station," J. Phys.: Conf. Ser. 234 (2010) 032008

24) A B Abrahamsen, N Mijatovic, E Seiler, T Zirngibl, C Træholt, P B Nørgård, N F Pedersen, N H Andersen and J Østergård: "Superconducting wind turbine generators," Supercond. Sci. Technol. 23 (2010) 034019

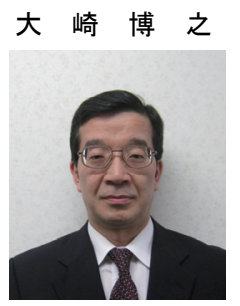

1961 年 3 月生。1983 年東京大学工学部電気 工学科卒業。1988 年同大学大学院工学系研究 科博士課程（電気工学専門課程）修了。1988 年東京大学工学部助手。2004 年同大学大学院 新領域創成科学研究科教授, 現在に至る。主 として超電導応用および電気機器・システム の研究に従事。低温工学・超電導学会, 電気 学会, IEEE 会員。工学博士。 